\title{
Evaluation of carotid calcifications in ambulatory dialysis patients
}

\author{
Evaluarea calcificărilor carotidiene la pacienţii dializaţi ambulator
}

\author{
Mircea Călin Țandrău' ${ }^{1}$ Oana Știrbu' ${ }^{1}$, Florica Gădălean², Cristina Vîrjan³ \\ Eliza Cetean', Călin Gheorghe Ciobanu ${ }^{4}$, Alin Neș ${ }^{1}$ \\ ${ }^{1}$ Spitalul Clinic Judeţean de Urgenţă, Arad, România \\ 2Spitalul Clinic Judeţean de Urgenţă Timişoara \\ ${ }^{3}$ Centrul de Dializă Avitum, Arad, România \\ "Universitatea de Vest „Vasile Goldiș“, Arad, România
}

\begin{abstract}
Vascular calcification and atherosclerosis are commonly associated with chronic terminal kidney disease (BCRT). The aim of the present study was to evaluate ultrasound the prevalence of calcifications and carotid plaques in BCRT patients treated with hemodialysis (HD), and to investigate the potential risk factors. The current observational-prospective study included 203 patients with BCRT, monitored for $48.5 \pm 19.0$ months and treated by hemodialysis in Arad county.

The main etiologies for BCRT were chronic glomerulonephritis in $32 \%$ of cases and diabetes in $22 \%$ of cases. $43.84 \%$ of patients had a mean carotid IMT value $\geq 0.9$. Carotid vascular calcification was found in 175 patients $(86.20 \%)$, most calcifications being located at the level of the carotid bifurcation on the posterior wall. 105 carotid plaques have determined stenosis of the vessel's diameter. The total number of carotid plaques and plaques as well as the average value of carotid IMT were associated with age. Vascular calcifications were directly associated with the presence of diabetes. A linear association relation between vascular calcifications and carotid plaques was found, the correlation coefficient being equal to 0.73 . Cardiovascular mortality was most strongly associated with the total number of carotid calcifications.

Ultrasound remains the only readily available technique, capable of highlighting the non-calcified plaque. Highlighting the vascular calcifications and the intuition of the pathophysiological mechanisms that contribute to their appearance may be factors influencing the therapeutic behavior applied to dialysis patients.
\end{abstract}

Keywords: vascular calcification, vascular plaque, carotid calcification, carotid plaque, dialysis patients

\section{REZUMAT}

Calcificările vasculare și ateroscleroza sunt frecvent asociate bolii cronice de rinichi terminale (BCRT). Scopul studiului actual a constat în evaluarea prin ultasonografie a prevalenței calcificărilor și a plăcilor carotidiene la pacienții cu BCRT tratați prin hemodializă (HD), respectiv investigarea potențialilor factori de risc. Studiul actu-al de tip observațional-prospectiv a inclus 203 pacienți cu BCRT, monitorizați pe o perioadă de 48,5 \pm 19,0 luni și tratați prin hemodializă la nivelul judeţului Arad.

Principalele etiologii pentru BCRT au fost glomerulonefritele cronice la $32 \%$ dintre cazuri şi diabetul zaharat la $22 \%$ dintre cazuri. $43,84 \%$ dintre pacienti au avut o valoare medie a IMT carotidian $\geq 0,9$. Calcificarea vasculară carotidiană a fost găsită la 175 pacienți $(86,20 \%)$, majoritatea calcificărilor fiind localizate la nivelul bifurcaţi-ei carotidei pe peretele posterior. 105 plăci carotidiene au determinat stenoze ale diametrului vasului. Numărul total de calcificări și plăci carotidiene, precum și valoarea medie a IMT carotidian s-au asociat cu vârsta. Calcificările vasculare s-au asociat direct și cu prezența diabetului zaharat. S-a constatat o relație de asociere linia-ră între calcificările vasculare și plăcile carotidiene, coeficientul de corelaţie fiind egal cu 0,73 . Mortalitatea cardiovasculară s-a asociat cel mai puternic cu numărul total de calcificări carotidiene.

Ecografia rămâne singura tehnică ușor disponibilă, capabilă să evidenţieze placa necalcificată. Evidenţierea calcificărilor vasculare şi intuirea mecanismelor fiziopatologice ce contribuie la apariţia lor pot constitui factori de influenţare a conduitei terapeutice aplicate pacienţilor dializaţi.

Cuvinte cheie: calcificări vasculare, plăci vasculare, calcificări carotidiene, plăci carotidiene, pacienţi dializaţi 


\section{INTRODUCERE}

Calcificările vasculare și ateroscleroza sunt frecvent asociate bolii cronice de rinichi terminale (BCRT). Boala arterială la pacienții cu BCRT se caracterizează prin calcificări extensive la nivelul atât al intimei, cât și al mediei vasculare. Calcificările arteriale intimale se asociază cu ateroscleroza, putând duce la stenoză și ocluzie arterială. Pe de altă parte, calcificările mediei se asociază cu arterioscleroza, ce cauzează creșterea stiffnes-ului arterial și creșterea valorilor tensiunii sistolice, cu alterarea perfuziei coronariene și hipertrofie ventriculară stângă (1). Numeroase studii au demonstrat relația directă între calcificările vasculare și creșterea riscului pentru evenimente cardiovasculare, respectiv creșterea mortalității la pacienții cu BCRT. Scopul studiului actual a constat în evaluarea prin ultasonografie Doppler (USD) a prevalenței calcificărilor carotidiene și a plăcilor carotidiene la pacienții cu BCRT trataţi prin hemodializă (HD), respectiv investigarea potențialilor factori de risc pentru apariția acestora.

\section{MATERIAL ŞI METODĂ}

Studiul actual, de tip observaţional-prospectiv, a inclus 203 pacienți cu BCRT (34\% femei, 41\% bărbaţi) având vârste cuprinse între 20 şi 84 ani, cu o vârstă medie de $61,5 \pm 13,8$ ani, monitorizați pe o perioadă de 48,5 $\pm 19,0$ luni și care au fost tratați prin hemodializă în sistem ambulator la nivelul judeţului Arad. Datele demografice și clinice au fost colectate printr-un examen clinic complet şi printr-o anamneză efectuată ambulator cu ocazia prezentării la dializă. Parametrii biologici au fost recoltaţi din sânge venos la iniţierea şedinţei de HD. Protocolul de desfășurare a studiului a respectat principiile etice conform declarației de la Helsinki și a fost aprobat de comisia etică, toți pacienții incluși exprimându-și acordul informat de includere în studiu.

Ecografia arterelor carotide a fost efectuată de acelaşi examinator cu experienţă în ecografia vasculară cu un ecograf EDAN omologat și o sondă liniară cu rezoluție înaltă și frecvență de bază de 7,5 MHz.

Grosimea intimă-medie (IMT) a fost stabilită prin măsurarea segmentului carotidei comune distale pe o lungime nu mai mică de $1 \mathrm{~cm}$, peretele de la acest nivel având un model de linie dublă bine definit. IMT-ul a fost măsurat bilateral la nivelul peretelui posterior. Dacă au existat plăci la acest nivel, acestea au fost incluse în valoarea IMT-ului. Determinarea IMT-ului a fost înregistrată la mo- mentul cu diametrul diastolic mai mic, folosind ca indicator de timp ECG-ul simultan.

Placa carotidiană a fost definită ca o îngroşare focală relativă la segmentele adiacente, cu o zonă distinctă de hiperecogenitate, sau protuzia în lumen a peretelui cu cel puţin $50 \%$ faţă de zona înconjurătoare (3).

Calcificarea carotidiană a fost definită dacă s-au identificat estompări ecografice ce decurg dintr-o leziune a peretelui arterial carotidian (4).

Utilizând evaluarea calcificărilor prin sistemul celor 6 segmente, au fost precizate următoarele caracteristici ale plăcilor/calcificărilor: existența, locația, principalele caracteristici geometrice și de suprafață și semnificația hemodinamică.

\section{REZULTATE}

În lotul studiat, durata medie a terapiei de substituţie a funcției renale prin HD a fost $68 \pm 62,22$ luni. Principalele etiologii care au determinat apariţia BCR la pacienţii studiaţi este reprezentată de glomerulonefritele primitive 62 pacienţi (30,38\%), nefropatie diabetică 45 pacienți $(22,05 \%)$ nefroangioscleroză 26 pacienți $(12,74 \%)$, polichistoză renală 25 pacienți $(12,25 \%)$, nefrită tubulo-interstițială 16 pacienți $(7,84 \%)$, nefropatii obstructive 6 pacienți $(2,94 \%)$, glomerulonefrite secundare 4 pacienți $(1,96 \%)$, în timp ce pentru 19 pacienţi $(9,31 \%)$ nu s-a putut preciza etiologia.

In tabelul 1 sunt prezentate valorile medii obținute pentru IMT-ul măsurat la nivelul arterei carotide comune drepte, respectiv pentru IMT-ul de la nivelul arterei carotide comune stângi. De asemenea, este menționat numărul de pacienți având o valoare a IMT $>=0,9$.

TABELUL 1. Rezultatele determinărilor IMT la grupul studiat

\begin{tabular}{|l|c|c|}
\hline Valoare IMT & $\begin{array}{c}\text { Carotida } \\
\text { comună dreaptă }\end{array}$ & $\begin{array}{c}\text { Carotida comună } \\
\text { stângă }\end{array}$ \\
\hline IMT mediu $(\mathrm{mm})$ & $0,733 \pm 0,13$ & $0,76 \pm 0,15$ \\
\hline IMT $>=0,9(\mathrm{~mm})$ & 36 & 53 \\
\hline IMT $>=0,9(\mathrm{~mm})$ bilateral & \multicolumn{2}{|c|}{10} \\
\hline
\end{tabular}

Prezența calcificării arteriale este evaluată ecografic la nivelul carotidei sub formă de plăci foarte ecogene cu o nuanță albă deschisă şi care prezintă con de umbră posterior. În prezent, se consideră că ecografia oferă un instrument relativ sensibil pentru detectarea calcificării vasculare carotidiene, datele obținute fiind calitative și sunt suficient de sensibile pentru urmărire pe termen scurt.

În tabelul 2 sunt prezentate rezultatele privind evaluarea numărului de plăci/calcificări, în terito- 
riul carotidian drept, respectiv stâng. Existența plăcii carotidiene a fost verificată în arterele carotide comune, interne și externe. A fost măsurat diametrul maxim al calcificării carotidiene de-a lungul peretelui arterei. Se observă că subcategoria cu 2 plăci/calcificări include cel mai mare număr de pacienți, respectiv plăci carotida dreaptă - 59 pacienți, plăci carotida stângă - 68 pacienți, calcificări carotida dreaptă -46 pacienţi şi calcificări carotida stângă - 54 pacienți. În lotul studiat, calcificarea vasculară carotidiană a fost găsită la 175 pacienți $(86,20 \%)$ din totalul de 203 , comparativ cu $28(13,79 \%)$ de pacienţi fără nicio calcificare la nivelul carotidelor.

TABELUL 2. Numărul de plăci/calcificări, în teritoriul carotidian drept, respectiv stâng

\begin{tabular}{|c|c|c|c|c|}
\hline $\begin{array}{c}\text { Număr } \\
\text { plăci/ } \\
\text { calcificări }\end{array}$ & $\begin{array}{c}\text { Număr } \\
\text { pacienți } \\
\text { plăci } \\
\text { dreapta }\end{array}$ & $\begin{array}{c}\text { Număr } \\
\text { pacienți } \\
\text { plăci } \\
\text { stânga }\end{array}$ & $\begin{array}{c}\text { Număr } \\
\text { pacienți } \\
\text { calcificări } \\
\text { dreapta }\end{array}$ & $\begin{array}{c}\text { Număr } \\
\text { pacienți } \\
\text { calcificări } \\
\text { stânga }\end{array}$ \\
\hline 1 & 38 & 36 & 44 & 44 \\
\hline 2 & 59 & 68 & 46 & 54 \\
\hline 3 & 53 & 48 & 48 & 42 \\
\hline 4 & 25 & 24 & 31 & 28 \\
\hline 5 & 14 & 16 & 15 & 19 \\
\hline 6 & 6 & 5 & 15 & 12 \\
\hline 7 & 4 & 2 & 1 & 1 \\
\hline 8 & 2 & 1 & 0 & 0 \\
\hline
\end{tabular}

În tabelul 3 este prezentată localizarea plăcilor/ calcificărilor în diferitele zone anatomice ale teritoriului vascular carotidian. Se observă că majoritatea calcificărilor au fost localizate la nivelul bifurcaţiei carotidei pe peretele posterior - $128(62,67 \%)$ în dreapta şi 97 (47,53\%) în stânga. La nivelul peretelui anterior, în dreptul bifurcaţiei carotidelor, au fost înregistrate 67 de calcificări în dreapta $(32,83 \%)$ şi 59 de calcificări în stânga $(28,91 \%)$. Doar 27 de pacienţi $(13,23 \%)$ au prezentat calcificări unice, restul prezentând calcificări multiple. 43 de pacienţi $(21,07 \%)$ au prezentat mai mult de 3 calcificări pe fiecare parte. Calcificarea arterelor carotide a fost evidenţiată unilateral la 38 de persoane $(18,62 \%)$ și bilateral la 137 de persoane (67\%). La 28 de pacienţi $(13,72 \%)$ nu s-au găsit calcificări carotidiene.

TABELUL 3. Localizarea plăcilor/calcificărilor în teritoriul vascular carotidian

\begin{tabular}{|l|c|c|c|c|}
\hline & \multicolumn{2}{|c|}{ Număr plăci } & \multicolumn{2}{c|}{$\begin{array}{c}\text { Număr } \\
\text { calcificări }\end{array}$} \\
\hline LOCALIZARE & Dr. & Stg. & Dr. & Stg. \\
\hline Carotida comună posterior & 14 & 10 & 58 & 67 \\
\hline Carotida comună anterior & 2 & 6 & 30 & 23 \\
\hline Bifurcație posterior & 23 & 25 & 128 & 97 \\
\hline
\end{tabular}

\begin{tabular}{|l|c|c|c|c|}
\hline & \multicolumn{2}{|c|}{ Număr plăci } & \multicolumn{2}{c|}{$\begin{array}{c}\text { Număr } \\
\text { calcificări }\end{array}$} \\
\hline Bifurcație anterior & 4 & 10 & 67 & 59 \\
\hline Carotida internă posterior & 10 & 5 & 57 & 64 \\
\hline Carotida internă anterior & 6 & 3 & 17 & 29 \\
\hline Carotida externă posterior & 4 & 0 & 19 & 11 \\
\hline Carotida externă anterior & 1 & 0 & 3 & 3 \\
\hline TOTAL & 64 & 59 & 379 & 353 \\
\hline
\end{tabular}

În studiul nostru, am observat că un număr de 105 plăci carotidiene au determinat stenoze ale diamentrului vasului în proporţii diferite (tabelul 4). Dintre acestea, $54(26,46 \%)$ au fost localizate pe carotida dreaptă, iar $51(24,99)$ pe carotida stângă. Doar 33 de plăci calcificate $(16,17 \%)$ au constituit stenoze semnificative hemodinamic $>50 \%, 19(9,31 \%)$ pe partea dreaptă şi $14(6,86 \%)$ pe partea stângă. Pacienţii cu stenoze prezintă risc crescut de accidente vasculare cerebrale și au fost îndrumaţi spre neurologie pentru evaluare. 5 persoane $(2,45 \%)$ au avut stenoză de 50-69\% și au urmat un tratament de prevenție medicală cardiovasculară și reexaminarea stenozei carotidiene la trei luni. 4 persoane aveau o stenoză de 70$85 \%$ a carotidei (una dintre acestea avea, de asemenea, o stenoză contralaterală de 50-69\%).

TABELUL 4. Plăci carotidiene - consecințe hemodinamice

\begin{tabular}{|c|c|c|c|c|c|c|}
\hline & \multicolumn{3}{|c|}{ Carotida dreaptă } & \multicolumn{3}{c|}{ Carotida stângă } \\
\hline $\begin{array}{c}\text { STENOZĂ } \\
\%\end{array}$ & $\begin{array}{c}\text { Carotida } \\
\text { comună }\end{array}$ & $\begin{array}{c}\text { Bifur- } \\
\text { cație }\end{array}$ & $\begin{array}{c}\text { Carotida } \\
\text { internă }\end{array}$ & $\begin{array}{c}\text { Carotida } \\
\text { comună }\end{array}$ & $\begin{array}{c}\text { Bifur- } \\
\text { cație }\end{array}$ & $\begin{array}{c}\text { Carotida } \\
\text { internă }\end{array}$ \\
\hline 10 & 3 & 0 & 0 & 1 & 0 & 0 \\
\hline 15 & 1 & 0 & 0 & 0 & 0 & 0 \\
\hline 20 & 6 & 0 & 0 & 6 & 2 & 0 \\
\hline 25 & 3 & 1 & 0 & 0 & 1 & 0 \\
\hline 30 & 6 & 1 & 0 & 5 & 3 & 1 \\
\hline 33 & 2 & 0 & 0 & 0 & 0 & 0 \\
\hline 35 & 1 & 0 & 0 & 1 & 0 & 0 \\
\hline 40 & 7 & 1 & 0 & 3 & 0 & 0 \\
\hline 45 & 3 & 0 & 0 & 2 & 0 & 0 \\
\hline 50 & 6 & 2 & 2 & 7 & 3 & 2 \\
\hline 55 & 0 & 0 & 0 & 1 & 0 & 0 \\
\hline 60 & 2 & 0 & 1 & 4 & 2 & 0 \\
\hline 62 & 1 & 0 & 0 & 0 & 0 & 0 \\
\hline 70 & 2 & 0 & 0 & 2 & 0 & 2 \\
\hline 71 & 0 & 1 & 0 & 0 & 0 & 0 \\
\hline 74 & 0 & 0 & 0 & 1 & 0 & 0 \\
\hline 75 & 0 & 1 & 0 & 2 & 0 & 0 \\
\hline 85 & 1 & 0 & 0 & 0 & 0 & 0 \\
\hline TOTAL & 44 & 7 & 3 & 35 & 11 & 5 \\
\hline & & & & & & \\
\hline
\end{tabular}

Privind relația factorilor de risc clasici și nonclasici cu apariţia calcificărilor şi a plăcilor carotidiene, am observat o asociere directă a numărului total de calcificări şi a numărului total de plăci cu vârsta. 
De asemenea, am constatat o relație de dependență a IMT carotidian cu vârsta, între acești doi parametri existând o corelaţie directă.

Am înregistrat o relaţie de asociere directă între diabetul zaharat și prezența calcificărilor vasculare. Analizând evoluţia numărului total de calcificări carotidiene şi cardiace în funcţie de vechimea diabetului zaharat, am observat că numărul calcificărilor creşte după 10 ani de evoluţie a diabetului, marea majoritate fiind evidente între 10 şi 30 de ani de evoluţie.

În ceea ce privește relația calcificărilor/plăcilor carotidiene cu hipertensiunea arterială (HTA), am observat tendința de aglomerare a numărului de pacienţi pe segmentul de durată a HTA de până la 20 de ani, restul pacienţilor oferind valori neglijabile. Repartizarea punctelor în plan denotă o corelaţie relativ redusă în funcţie de HTA, fapt certificat de valori de 0,143 ale indicelui Pearson pentru calcificările carotidiene.

Analiza interrelației calcificări carotidiene plăci carotidiene a relevat faptul că există o dependență pozitivă ridicată a numărului de calcificări cu numărul total de plăci, coeficientul de corelaţie fiind egal cu 0,73 (Fig. 1).
Studiul relației între decesele de cauză cardiovasculară şi prezența unei valori crescute a IMTului carotidian, a plăcilor și calcificărilor carotidiene, prezentat în fig. 2, a subliniat faptul că mortalitatea cardiovasculară s-a asociat cel mai puternic cu numărul total de calcificări carotidiene (Fig. 2).

\section{DISCUȚII}

Pe lotul studiat, principalele etiologii pentru BCRT au fost glomerulonefritele cronice la $32 \%$ dintre pacienți, respectiv diabetul zaharat la $22 \%$ dintre cazuri. $43,84 \%$ dintre pacienți au avut o valoare medie a IMT carotidian $\geq 0,9$. Calcificarea vasculară carotidiană a fost găsită la 175 pacienți $(86,20 \%)$, majoritatea calcificărilor fiind localizate la nivelul bifurcaţiei carotidei pe peretele posterior. În ceea ce privește plăcile şi calcificările carotidiene, am observat faptul că, dintre acestea, $105 \mathrm{au}$ determinat stenoze ale diamentrului vasului, având severităţi diferite. De asemenea, numărul total de calcificări și plăci carotidiene, precum și valoarea medie a IMT carotidian s-au asociat cu vârsta. Calcificările vasculare s-au asociat direct și cu prezența diabetului zaharat. De asemenea, am constatat o

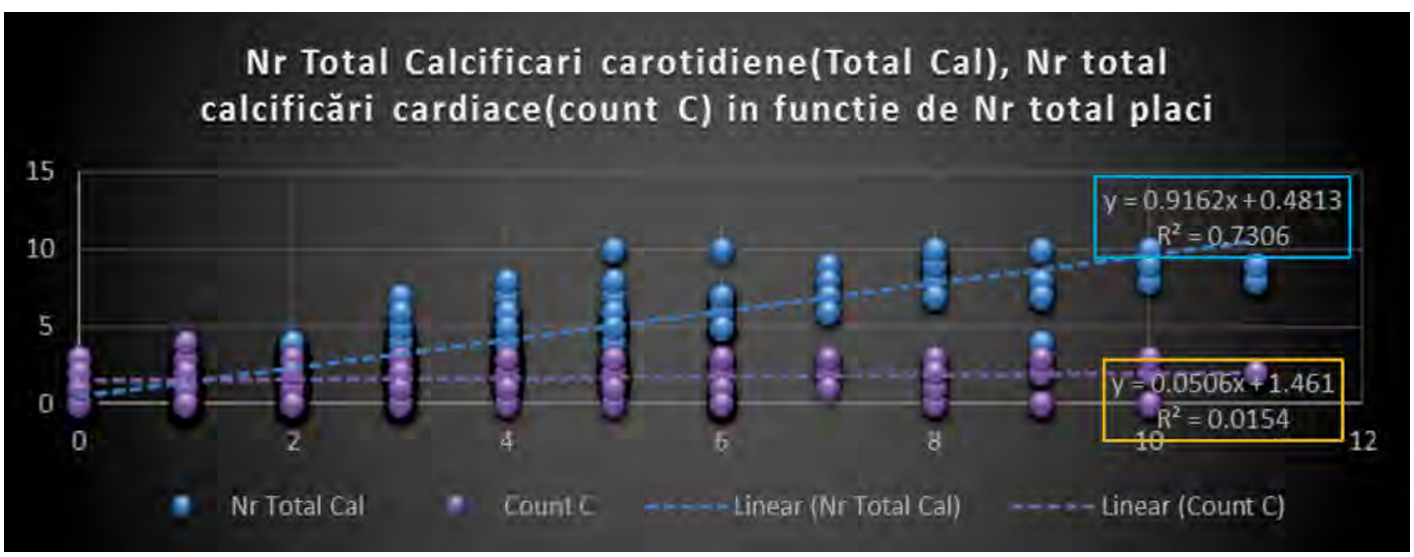

FIGURA 1. Asocierea calcificări carotidiene - plăci carotidiene

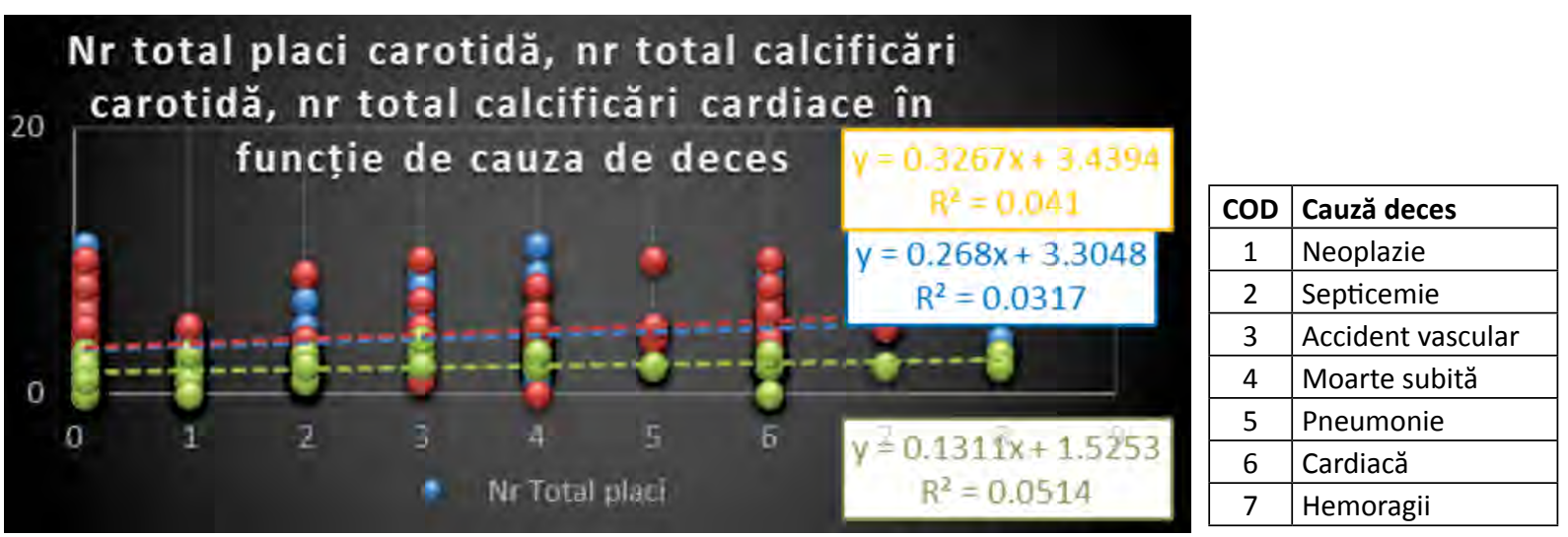

FIGURA 2. Asocierea mortalitate cardiovasculară - plăci/calcificări vasculare 
relație de asociere liniară între calcificările vasculare și plăcile carotidiene, coeficientul de corelaţie fiind egal cu 0,73. În studiul nostru, mortalitatea cardiovasculară s-a asociat cel mai puternic cu numărul total de calcificări carotidiene.

Creşterea indicelui de grosime intimă-medie este unul din cele mai precoce semne ale afectării vasculare aterosclerotice. IMT $>\geq 0,9 \mathrm{~mm}$ şi/sau prezența plăcilor discrete sunt considerate markeri ai aterosclerozei. Un IMT carotidian crescut este considerat o leziune critică pentru dezvoltarea ateromului. Numărul de plăci carotidiene, IMT și remodelarea arterială sunt considerate predictori ai aterosclerozei accelerate (5).

S-a crezut iniţial că prezenţa calcificărilor vasculare la pacienţii cu BCR este consecința unui proces pasiv de suprasaturare a plasmei cu calciu şi fosfat. A devenit însă evident în ultimii ani faptul că formarea şi progresia calcificărilor vasculare reprezintă un proces celular activ, reglat prin factori umorali şi celulari (6).

În studiul nostru, vârsta a reprezentat un factor de risc pentru apariția plăcilor/ calcificărilor carotidiene, precum și pentru creșterea IMT-ului carotidian. Acestă constatare este în concordanță cu literatura (7) şi atestă participarea aterosclerozei în geneza calcificărilor vasculare evidențiate în lotul studiat. De fapt, rigidizarea arterială este un semn distinctiv al procesului de îmbătrânire, din cauza modificărilor structurii și remodelării peretelui arterei (8).

Privind factorii de risc tradiţionali care generează ateroscleroza, în studiul actual am observat o corelaţie semnificativă între prezența calcificărilor vasculare şi prezența diabetului zaharat fie ca afecţiune generatoare a bolii cronice de rinichi, fie ca afecţiune însoţitoare, uneori apărută tardiv în stadii avansate ale BCR (9). Se pare că acele calcificări cu valori mari apar după 10 ani de evoluţie a diabetului, marea majoritate fiind între 10 şi 30 de ani de evoluţie. De asemenea, se poate concluziona că durata evoluţiei diabetului nu influenţează în mod direct creşterea numărului de calcificări. Diabetul zaharat de tip 2 reprezintă un factor de risc pentru progresia mortalității cardiovasculare, exacerbată de dezvoltarea insuficienței renale cronice secundare nefropatiei diabetice, care necesită hemodializă pe termen lung (10).

În studiul nostru, a existat o asociere slabă a numărului de plăci/calcificări carotidiene cu HTA. Există dovezi din mai multe studii, precum şi din practica clinică de zi cu zi, că este destul de slab realizat controlul tensiunii arteriale la un număr semnificativ de pacienți dializați, în comparație cu țintele recomandate de ghidurile actuale (11). Cauza principală a fost identificată ca fiind dificultatea obținerii unei greutăți uscate optime, însoțită de o creștere în greutate interdialitică, de obicei mare, și a unui aport de sodiu dietetic, adesea excesiv (12). Este foarte probabil că atât ateroscleroza, caracterizată printr-o creștere a IMT, cât și rigidizarea arterială, caracterizată printr-o reducere a complianței arteriale, să se dezvolte timpuriu în cursul BCR, fiind mai accentuată la pacienții cu boală renală în stadiu terminal, fie că sunt trataţi cu dializă peritoneală sau prin hemodializă. Această presupunere este susținută de rezultatele unui studiu (13) care a arătat că a fost redus semnificativ coeficientul de distensibilitate a arterei carotide obişnuite la pacienții cu BCR hemodializaţi, comparativ cu controalele. Acest lucru indică o rigidizare crescută a arterelor mari pe întregul spectru de insuficiență renală (14). Mai mult, coeficientul de distensibilitate a arterei carotide comune a fost corelat semnificativ cu gradul de insuficiență renală la pacienții cu BCR. Motivul pentru o complianţă redusă a arterei carotide comune la pacienții renali este, probabil, multifactorial. O parte a diferentei în ceea ce privește distensibilitatea arterială între subiecții de control sănătoși și pacienții renali se explică prin niveluri mai crescute ale tensiunii arteriale la toate grupurile de pacienți renali comparativ cu grupul de control, în ciuda tratamentului antihipertensiv. $\mathrm{Cu}$ toate acestea, influența altor factori în afara HTA per se asupra distensibilităţii peretelui arterial este sugerată de observația că distensibilitatea arterială a fost redusă și la pacienții cu HD cu durate lungi ale ședinţelor (15) și prin faptul că nivelul insuficienței renale a fost legat în mod semnificativ de distensibilitatea comună a arterei carotide, indiferent de vârstă și controlul TA (13). Nivelul funcției renale per se pare a fi asociat mai semnificativ cu distensibilitatea arterială redusă decât factorii secundari, cum ar fi metabolismul calciului și fosfatului.

Calcificările carotidiene sunt în strânsă relație cu prezența plăcilor carotidiene, aceste două variabile fiind dependente una de cealaltă într-o formă liniară.Plăcile iau naștere cel mai frecvent în artera carotidă comună și se extind distal în artera carotidă internă. Bifurcația arterei carotide cervicale oferă un loc în care evoluția aterosclerozei poate fi monitorizată reproductibil și neinvaziv. Deși ecografia este cea mai obișnuită metodă de screening pentru cuantificarea aterosclerozei carotidei (măsurarea grosimii intimă-medie, compoziţia plăcii și procentul stenozei), ea este mai puțin precisă decât CT-ul standard în cuantificarea calcificării arterei carotide (16). 
Compoziția relativă a plăcilor carotide este importantă în evaluarea stabilității plăcii carotide, deoarece majoritatea studiilor sugerează că plăcile carotide simptomatice sunt mai susceptibile de a se complica prin ulcerații, mai puțin organizate și hemoragice (17), în timp ce plăcile calcifiate sunt asociate cu mai puține simptome vasculare cerebrale (18). Astfel, se pare că încărcarea plăcii cu calciu la nivel carotidian nu reflectă nici sarcina aterosclerotică a plăcii și nici compoziția sau instabilitatea plăcii (19).

În studiul nostru, mortalitatea cardiovasculară s-a asociat cel mai puternic cu numărul total de calcificări carotidiene. În literatura de specialitate, creșterile IMT-ului carotidian sunt asociate cu risc crescut de infarct miocardic și accident vascular cerebral la subiecții dializaţi (20). În schimb, alte studii demonstrează mai degrabă o corelație mai bună a măsurării diametrului plăcii decât a IMT-ului cu evenimentele aterosclerotice (21).

\section{BIBLIOGRAFIE}

1. Nakayama M, Ura $Y$, Nagata M, Okada $Y$, Sumida $Y$, Nishida K et al. Carotid artery calcification at the initiation of hemodialysis is a risk factor for cardiovascular events in patients with end-stage renal disease: A cohort study. BMC Nephrol. 2011; 12:56.

2. Patel ML, Radheyshyam, Verma A, Sachan R, Kamal R. Impact of Carotid Intima-Media Thickness on Long-term Outcome in Hemodialysis Patients. North Am J Med Sci. 2015; 7:281-87.

3. Welby JP, Kim ST, Carr CM, Lehman VT, Rydberg CH, Wald JT, Luetmer PH, Nasr DM, Brinjikji W. Carotid Artery Tortuosity Is Associated with Connective Tissue Diseases. AJNR Am J Neuroradiol. 2019 Oct;40(10):1738-1743.

4. Appleton CP: Carotid artery disease - Diagnosis and treatment Mayo Clinic. Available at. https://www.mayoclinic.org/diseases-conditions/carotid-artery-disease/diagnosis-treatment/drc-20360527.

5. Pei-ChunChen, Jiann-Shing Jeng, Hsiu-Ching Hsu, Ta-Chen Su4, Kuo-LiongChien, Yuan-Teh Lee. Carotid Atherosclerosis Progression and Risk of Cardiovascular Events in a Community in Taiwan - Scientific Reports. Available at. https://www.nature.com/articles/srep25733.

6. Moe SM, Chen NX. Pathophysiology of vascular calcification in chronic kidney disease. Circ Res. 2004 Sep 17;95(6):560-7.

7. Meissner I, Khandheria BK, Sheps SG, Schwartz GL, Wiebers DO, Whisnant JP, Covalt JL, Petterson TM, Christianson TJ, Agmon Y. Atherosclerosis of the aorta: risk factor, risk marker, or innocent bystander? A prospective population-based transesophageal echocardiography study. J Am Coll Cardiol. 2004 Sep 1; 44(5):1018-24

8. Najjar SS, Scuteri A, Lakatta EG. Arterial aging: Is it an immutable cardiovascular risk factor? Hypertension. 2005 Sep;46(3):454-62.

9. Mori H, Torii S, Kutyna M, Sakamoto A, Finn AV, Virmani R. Coronary Artery Calcification and its Progression: What Does it Really Mean? JACC Cardiovasc Imaging. 2018; 11:127-42.

10. Mizobuchi M, Towler D, Slatopolsky E. Vascular calcification: The killer of patients with chronic kidney disease. J Am Soc Nephrol. 2009 Jul; 20(7):1453-64

11. Xue JL1, Frazier ET, Herzog CA, Collins AJ. Association of heart disease with diabetes and hypertension in patients with ESRD. Am J Kidney Dis. 2005 Feb;45(2):316-23.

\section{CONCLUZII}

Studiul prezent nu a putut demonstra o legătură directă între numărul de calcificări, anumite localizări, numărul şi severitatea lor, nivelul şi durata de acţiune a factorilor de risc convenţionali sau neconvenţionali. Importanța evidenţierii lor constă însă și în posibilitatea de a influenţa mecanismele fiziopatogenice care duc la formarea lor.

Ecografia rămâne singura tehnică ușor disponibilă, capabilă să evidenţieze placa necalcificată. Evidenţierea calcificărilor vasculare şi intuirea mecanismelor fiziopatologice ce contribuie la apariţia lor pot constitui factori de influenţare a conduitei terapeutice aplicate pacienţilor dializaţi.

Având în vedere numărul mare de pacienţi la care s-au pus în evidenţă calcificările prin ecografie vasculară, se poate concluziona că această metodă este deosebit de utilă în depistarea calcificărilor vasculare la pacienţii dializaţi ambulator.

12. Bakris G, Agarwal R. Managing Hypertension in the Dialysis Patient - Complicated and Important. Available at https://www.medscape. com/viewarticle/733263.

13. Coll B, Betriu A, Martínez-Alonso M, Amoedo ML, Arcidiacono MV, Borras $M$ et al. Large Artery Calcification on Dialysis Patients Is Located in the Intima and Related to Atherosclerosis. Clin J Am Soc Nephrol CJASN. 2011; 6:303-10.

14. Polak JF, Pencina MJ, Pencina KM, O’Donnell CJ. Carotid-wall intima-media thickness and cardiovascular events. N Engl J Med. 2011 Jul 21;365(3):213-21.

15. Kerr P. Frequent Long Dialysis : Why Do Length and Frequency Help? | Kidney News. Available at https://www.kidneynews.org/kidney-news/ features/frequent-long-dialysis-why-do-length-and-frequency-help.

16. Denzel C, Lell M, Maak M, Höckl M, Balzer K, Müller KM et al. Carotid Artery Calcium: Accuracy of a Calcium Score by Computed Tomography - An In vitro Study with Comparison to Sonography and Histology. Eur J Vasc Endovasc Surg. 2004; 28:214-20.

17. Sterpetti AV, Schultz RD, Feldhaus RJ, Davenport KL, Richardson M, Farina $\mathrm{C}$ et al. Ultrasonographic features of carotid plaque and the risk of subsequent neurologic deficits. Surgery. 1988; 104:652-60.

18. Nandalur KR, Baskurt E, Hagspiel KD, Phillips CD, Kramer CM. Calcified Carotid Atherosclerotic Plaque Is Associated Less with Ischemic Symptoms Than Is Noncalcified Plaque on MDCT. Am J Roentgenol. 2005; 184:295-98.

19. Shaalan WE, Cheng H, Gewertz BL, Mckinsey JF, Schwartz LB, Katz $\mathrm{D}$ et al. Degree of carotid plaque calcification in relation to symptomatic outcome and plaque inflammation. J Vasc Surg. 2004; 40:262-69.

20. Nishizawa Y, Shoji T, Maekawa K, Nagasue K, Okuno S, Kim M et al. Intima-media thickness of carotid artery predicts cardiovascular mortality in hemodialysis patients. Am J Kidney Dis. 2003; 41:S76-79.

21. Ravani A, Werba JP, Frigerio B, Sansaro D, Amato M, Tremoli E et al. Assessment and relevance of carotid intima-media thickness (C-IMT) in primary and secondary cardiovascular prevention. Curr Pharm Des. 2015; 21:1164-71. 